\title{
NARRATIVES OF SEXUALITY IN BUGIS AND MAKASAR MANUSCRIPTS
}

\author{
Muhlis Hadrawi ${ }^{* 1}$ \\ Fakultas Ilmu Budaya, Hasanuddin University \\ Jalan Perintis Kemerdekaan KM 10 \\ Makassar, Sulawesi Selatan, Indonesia \\ email:muhlisbugis@yahoo.com
}

Published online: 15 September 2016

To cite this article: Hadrawi, M. 2016. Narratives of sexuality in Bugis and Makasar manuscript, trans. Druce, S. C. In Orality, writing and history: The literature of the Bugis and Makasar of South Sulawesi, ed. Druce, S. C. International Journal of Asia Pacific Studies 12 (Supp. 1): 187-206, http://dx.doi.org/10.21315/ijaps2016.12.s1.9

To link to this article: http://dx.doi.org/10.21315/ijaps2016.12.s1.9

\begin{abstract}
This paper discusses a particular category of text called assikalaibineng, which contain a range of Bugis and Makasar knowledge relating to sexual procedure and relations for married couples. The sexual knowledge in these texts was mainly restricted to members of Sufi tariqa, in particular the elite, and assikalaibineng sexual knowledge was shaped by both indigenous practices and Islamic values and Sufi teachings. In this paper, I focus on the following assikalaibineng sexual knowledge: the ideology and symbols of assikalaibineng, actions to be taken by newlyweds, and the detailed threestage procedure a couple should follow during sexual intercourse. In addition, I discuss the Sufi links to assikalaibineng knowledge and the problematic textual transmission of this knowledge.
\end{abstract}

Keywords: Bugis and Makasar sexual culture, sex, Sufism, Bugis and Makasar literature, assikalaibineng 
Since writing developed in South Sulawesi at the beginning of the 15th century, the Bugis and Makasar ${ }^{2}$ peoples have recorded various aspects of their culture, knowledge and history in written form. ${ }^{3}$ Most of these writing are found in thousands of paper manuscripts of European origin that contain copies of earlier texts and are today an important part of South Sulawesi's cultural heritage. A little known category of text found in these manuscripts are conventionally called assikalaibineng, which means "concerning husband-wife [sexual] relations." Collectively, these texts impart a wide range of Bugis and Makasar knowledge about sexuality and sexual relations that is strongly influenced by Islamic values, in particular, Sufi teachings. Information in one text suggests that the original source of assikalaibineng knowledge was the 17th century Makasar ulama (Islamic scholar) and mystic, Syekh Yusuf, who introduced the Khalwatiyya tariqa (mystical order) to South Sulawesi. Knowledge of assikalaibineng, in either written or oral form, appears to have been largely restricted to political and religious elites who followed the Khalwatiyya tariqa that, for much of its history at least, excluded commoners. In the 20th century assikalaibineng knowledge may have become more widespread with the expansion of the Khalwatiyya Samman, a related tariqa that attracted many people of common birth.

Texts containing assikalaibineng knowledge can thus be described as repositories of Bugis and Makasar sexual knowledge shaped by Islamic values and Sufi teachings. They are not, however, concerned only with sexual intercourse and methods but present a wide range of knowledge on husband-wife sexual relations that help to develop and maintain harmony for a couple throughout their lives. This knowledge includes the psychology of sexual relations, how to withhold ejaculation, Islamic prayers and mantras spoken during intercourse, determining the future gender and personal qualities of a child, natural birth control, the best and worst times for sexual intercourse, cleanliness of the body and how to maintain its youth, medical treatment of genitalia, instructions for newlyweds, and an explanation of the different stages that should be followed when engaging in sex (Hadrawi 2008).

There is not space here to discuss all aspects of assikalaibineng knowledge found in texts and this article focuses mainly on the following: the ideology and symbols of assikalaibineng, actions to be taken by newlyweds, and the detailed three-stage procedure a couple should follow during sexual intercourse. In addition, I discuss the Sufi links to assikalaibineng knowledge and the problematic textual transmission of this knowledge. I begin with a brief discussion of the sources. 


\section{SOURCES}

The sources for the study are derived from manuscript texts held in the microfilm collection of South Sulawesi manuscripts held at the Makassar Branch of the Indonesian National Archives. The microfilm catalogue (Paeni et al. 2003) indicated there were 44 assikalaibineng texts in this collection but upon accessing the microfilm reels only 28 could be located, 11 of which proved to be unreadable. ${ }^{4}$ Of the 17 remaining texts, which form the sources for this study, most are written in the Bugis language and script but importantly, several are written in the Makasar language. Referencing of the texts used in this article follows the numbers set out in the microfilm catalogue. For example, Arsip Nasional Republik Indonesia di Makassar (ANRIM) 33/40 refers to the 40th manuscript on microfilm number 33.5

\section{THE SUFI ORIGINS AND CONNECTIONS OF ASSIKALAIBINENG}

A single assikalaibineng text, or manuscript, containing all known assikalaibineng knowledge probably never existed and, as I show below, there does not appear to have been any systematic transmission of these texts as some copyists employed degrees of creativity. This makes it difficult to establish relationships between texts and to trace the origin, transmission and any developments in assikalaibineng knowledge that may have taken place over time. Fortunately, several texts do have brief colophons that provide clues to the origin of assikalaibineng and the personages linked to this knowledge. One of these colophons (ANRIM $45 / 23$, p. 14) indicates that the original source of assikalaibineng was the great 17th century Makasar ulama Syekh Yusuf, the founder of the Khalwatiyya tariqa in South Sulawesi that was taught specifically to the Bugis and Makasar aristocracy. ${ }^{6}$ This colophon first mentions Syekh Yusuf as the founder of this tariqa and then states he was the source of the text's assikalaibineng knowledge: "This was set down by Petta Tosalama'é ${ }^{7}$ of Gowa, the one called the Syekh, who achieved pure spiritual knowledge of God" (Makkuniro pattarona Petta Tosalama'é ri Gowa riasengngé Saéhe' Toripaccingié rahasiana ri Yalla Taala). Syekh Yusuf may have set down this assikalaibineng knowledge in written form but given the close relationship between orality and writing in South Sulawesi (see Pelras 2016) it is reasonable to assume that it was disseminated in both oral and written form. 
What seems clear from the above information is that assikalaibineng knowledge was initially linked to the Khalwatiyya tariqa, which was essentially restricted to the ruling elite. These elite did not simply discourage commoners from following the teachings of this tariqa but often forbade them. For example, the Khalwatiyya tariqa follower La Tenri Tappu Ahmad Salih Syamsuddin, who ruled the Bugis kingdom of Boné from 1775-1812, explicitly refused to allow commoners to study this tariqa as he believed that such spiritual knowledge was an exclusive right of the palace elite (Bruinessen 1999: 295). Such a pattern of exclusivity was also applied to assikalaibineng, which is why the vast majority of texts that disclose this knowledge were owned and reproduced within palaces or in surau associated with them. ${ }^{8}$

During the 20th century this may have changed with the growth of another tariqa, the Khalwatiyya Samman, which is less aristocratic that the Khalwatiyya tariqa introduced by Syekh Yusuf. The Khalwatiyya Samman first developed in South Sulawesi during the 18th century and initially there appears to have been a degree of overlap between the two tariqa. However, in the late 19th century, under the leadership of a lower ranking Bugis noble called Haji Abd ar-Razzaq (better known as Haji Palopo), a strict separation between the two was established. From this time, the Khalwatiyya Samman became increasingly popular and attracted and accepted many people of common birth (Bruinessen 1991: 258-259; Pelras 1996: 290).

Twentieth century Khalwatiyya Samman leaders were also linked to the ownership and production of assikalaibineng texts and knowledge. Evidence of this link is found in a second colophon (ANRIM 45/23, p. 10) that informs us that Syekh Abdullah was the source of knowledge for this text: "This information is for those who administer shari'a teachings. It was set down by Syekh Abdullah to his four children and is for the benefit of the two villages" (makkoniro pappéesse'na to pégau' éngngi adanna sara'é annessa-nessana Syaikh Abdullah ri nénéna ri anaqna ri eppaél pasalama' éngngi ri wanuwaé duwaé). The colophon gives no further information about Syekh Abdullah but it is not difficult to identify him. He was the son of Haji Palopo and succeeded his father as Khalwatiyya Samman leader in the early 20th century. He also had the title Puang Lompo (the highest teacher).

Syekh Abdullah played an important role in further popularising and expanding this tariqa among the Bugis and Makasar (Bruinessen 1991: 262; Hamid 1994: 220). However, his success became a cause of concern for the Dutch and, in particular, ulama outside the tariqa, who believed his and the Khalwatiyya Samman's increasing popularity undermined their authority. In an attempted to discredit leader and tariqa numerous anonymous letters 
were sent out accusing them of heretic teachings and immoral behaviour and practices. Further anonymous letters sent to the Dutch that claimed the tariqa were conspiring against them. Eventually, Syekh Abdullah stepped down as leader in order to protect the Khalwatiyya Samman, which not only survived these attacks but also became South Sulawesi's largest religious group. ${ }^{9}$

\section{THE TRANSMISSION OF ASSIKALAIBINENG TEXTS}

Philological analysis of extant readable assikalaibineng texts reveals that there was no systematic transmission. While a few appear to be faithful copies of originals, many are not as copyists often exercised creativity and amalgamated two or more written or oral sources to create a new text. Most assikalaibineng texts can thus be described as new "works" in the sense meant by Macknight (1984). This does not mean that "copyists" felt free to elaborate and innovate as they pleased. From the limited information available it appears that they based their work on existing sources, both oral and written, which were brought together to create a new text. Other copyists appear to have simply rewritten an existing source in their own style. In the context of this transmission of knowledge, we should remain mindful of the close relationship between orality and writing in South Sulawesi as "texts" frequently move from one register to the other (Pelras 2016). This does not of course preclude the possibility that assikalaibineng knowledge was developed and expanded over time under the direction of tariqa leaders.

My analysis of extant readable assikalaibineng texts identifies five main ways they have been reproduced from earlier works: ${ }^{10} 1$ ) texts directly copied from an earlier text; 2) texts created from two or more written sources that focus on different topics with the result being a new expanded work; 3) texts copied from an earlier text derived from oral information; 4) texts derived from the same written (or oral) source material but vary significantly in style and structure from each other and the source text; 5) Some texts were created from a combination of written and oral sources.

The variety of methods used in the transmission make it impossible to establish a broader relationship between assikalaibineng texts, even where two texts have a similar content. For example, ANRIM 48/5 and 48/10 are both concerned with sexual intercourse methods and the similarity of their contents suggests they share a common origin. However, the structural and linguistic variation between them makes it impossible to establish a 
relationship. The same is true of ANRIM 23/33 and 45/27 that tell of marriage jurisprudence and protocol.

Of the assikalaibineng texts I located, the most complex, but also the most informative, are found on pages 64 to 83 of ANRIM 33/40. These pages contain eight separate topics placed one after the other all produced by the same unnamed individual that collectively constitute a single overall work. This work is an anthology and its writer used various sources in its creation, both written and oral assikalaibineng knowledge. ${ }^{11}$ The oral element of this work is clear from a colophon on page 77 that informs us that both oral and written sources were used:

The person who wrote this [text] said: "These words I once heard spoken. I have placed them in this Bugis writing in their entirety, whether right or wrong."

Makkedai to mmokiéngngi/ naiya adaéwél ritu pura uwéngkalingai/ ripataretté'/ kupannessai ri sure' Ogié/ Naiya apatujunna enrengngé apasalanna/ (ANRIM 33/40, p. 77).

This work imparts a wide range of assikalaibineng knowledge and in a previous analysis (Hadrawi 2008) I considered it the most exceptional of all assikalaibineng texts I examined, primarily because it contains considerable material not found in other texts. This material includes guidance on husband and wife sexual intercourse, specific actions to be carried out by a husband towards a wife before and after sexual intercourse, specific guidance for newlyweds and medical knowledge for treating the female vagina for smells and leucorrhoea. In the following pages I draw mainly on this work.

\section{THE IDEOLOGY AND SYMBOLS OF ASSIKALAIBINENG}

For the Bugis and Makasar, assikalaibineng knowledge represents a didactic sexual narrative for husband and wife that provides insights and knowledge into the complex sexual relations of a married couple. This is not exclusively concerned with biological sexual knowledge but also has a deep religious meaning linked to the creation of life; sex is both a biological and religious process that, by the will of God, can lead to the birth of a child. In assikalaibineng, sex between a husband and wife essentially functions as a symbol for the creation of life, which God ultimately determines. This is set out in a special symbolic theological dialogue between a baby's ruh (spirit) 
and God that represents a "contract of life." Contained within this contract is the concept that a baby's ruh has willingly committed itself to perform obligations to God in its future life and has received God's blessing to emerge from the womb into the world. ${ }^{12}$ The basis of this narrative appears to be based on verse 172 of Surah Al-A'raf of the Holy Quran, the basic meaning of which is given below:

When your Lord took from the Children of Adam, from their loins, their descendants and made them bear witness over themselves, [He said to them,] "Am I not your Lord?" They said, "Yes indeed! We bear witness." [This,] lest you should say on the Day of Resurrection, "Indeed we were unaware of this."

This verse contains the meaning that humans are the servants of God who are born into the world to serve and follow his instructions while distancing themselves from what he forbids. This is a reason why the adzan (call to prayer) is spoken into the right ear of the baby and iqamah (the second call to prayer) in the left after birth as this serves to remind the baby of the contract that was made with God.

Related to this and verse 172 Surah a-A'raf is the important concept in assikalaibineng knowledge of the need to continually speak prayers and mantras in praise of God during sexual intercourse. These prayers and mantras represent a form of religious communication between the couple and God and their importance is repeatedly emphasised in assikalaibineng texts. A husband and wife should never forget God during sexual intercourse and prayers and mantras in praise of Him accompany each sexual act. This helps connect the couple's minds to God and ensure their souls remain clean during sexual intercourse. Without prayers and mantras, sexual intercourse would lose its religious importance and significance. This would mean the couple were merely satisfying their desire in a sinful way and acting like animals. Sexual intercourse that lacks communication with God may also adversely affect the personality or behaviour of a child conceived during the act.

Two important Islamic personages that feature prominently in assikalaibineng narratives are Sayyidina Ali, a friend and cousin of the Prophet Mohammad, and his wife, Fatimah az-Zahra, a daughter of the Prophet. These two figures symbolise sexual relations between husband and wife and in Islamic marital behaviour are identified as idea people. In assikalaibineng knowledge, which is didactically part of mystical Sufi sexual instruction, they function as exemplars and sources of everyday 
sexual ethics who provide guidance when engaging in sexual intercourse. Ali also represents the penis and Fatimah the vagina (Hadrawi 1999: 32). Both figures are revered in the Muslim world and several Sufi tariqa, including the Khalwatiyya, trace their spiritual lineage to Muhammad through Ali (Campo 2004: 26) while many Sufis also believe that the spiritual knowledge of a syekh is directly inherited from Ali (Steigerwald 2004: 38). Fatimah has a special place in the Muslim world and "in her marriage to Ali" represents the ideal wife (Andaya 2006: 91). In sexual activity assikalaibineng teaches that a couple should implement the principles of Ali and Fatimah and follow this all of their lives as this is correct sexual behaviour and provides a positive and noble meaning to sexual intercourse. This should begin on the first night of marriage, where Ali and Fatimah are of particular importance.

\section{NEWLYWEDS AND THE INNER SPIRITUAL MARRIAGE}

For the Bugis and Makasar, the first night a couple spend together following marriage is a key moment as this is when they embrace mutuality in their sexual life together and ideally lead to happiness as life partners. It is important to note that in traditional Bugis and Makasar society marriage rarely developed from a couple's mutual acquaintance, courtship or familiarity. Parents and the wider family generally arranged marriages and most couples had no intimate relationship beforehand, while some may not have even met. This lack of familiarity meant that on the first night newlyweds faced a wholly new and unfamiliar situation. A wife may not be mentally prepared for sex and feel ashamed or embarrassed before her husband, or even reject his sexual advances. A husband may also feel ashamed and be unprepared.

In order to overcome these potential problems and ensure future sexual harmony, assikalaibineng texts set out a specific inner spiritual marriage for newlyweds that takes place before sexual union. In addition, they are expected to follow a specific three-stage guidance on sexual procedure set out for a couple, which I address later. The inner spiritual marriage in assikalaibineng symbolises unity between the newlywed's physical body and inner selves. This sacred act should lead to the couple's future happiness. Performing this inner spiritual marriage includes specific actions and utterances that are followed by tafakkur (contemplation, intellection) that focuses the heart and soul as God's creations. Ali and Fatimah, the ideal couple, are the symbols and assikalaibineng texts indicate 
that this inner spiritual marriage is based on actions believed to have been carried out by them:

Before sex with your wife for the first time, both of you should meditate. Focus your inner selves, see yourself and see your wife in your mind's eye. Hold her upper arm, say the greeting, assalamu alaikum, followed by the words "Ali is holding, Fatimah is held." Still holding her say the syahadat: Asyhadu Allaa ilaaha illaahuu wa asyhadu anna Muhammad Rasulullah. Now say these words in your heart, "Gabriel marry me [to her], Muhammad is my witness, my witness to the will of God. Let it be so. Then you kiss her, and follow with foreplay. This is the order concerning obligatory actions according to the way of Ali and Fatimah.

Naiya bunge' sitako makkunraimmu tapakkoro'ko riyolo'/ Mupakkitai mata atimmu ita alému Alepu'/ Muita lapaleng Ba-i makkunraimmu/ Muinappa kkarawai limanna mubérésellengiwi makkedaél Assalamu alaikum I Yali makkarawa Patima rikarawa/ Narékko muwarekkenni limanna powadani sahada'-él Asyhadu Allaa ilaaha illaahu wa asyhadu anna Muhammad Rasulullah/ Nakkedana atimmu Ajiberaélé panikaka'Muhamma' walliya' Uwallié sabbiya' pangélorenna Alla Taala kumpayakung/ Muinappa ppalanni pabbaummu culé-culému iyamaneng/ Makkonitu taretté'na riasengngé gau' parellu pakéna I Ali na Patima/ (ANRIM 33/40, p. 76-70).

\section{HUSBAND-WIFE SEXUAL RELATIONSHIP: THE THREE STAGES}

Sexual intercourse in assikalaibineng texts is conceived of as a three-stage process: flattery and foreplay (macculé-culé) the act of sexual intercourse (barattemmu) and cleaning and care of the body (taretté'). Texts give a detailed and clear description of each of the stages in order to achieve good quality sexual intercourse. These stages of sexual intercourse are set out as follows. 


\section{Macculé-culé: The First Stage}

The first stage of sex set out in assikalaibineng texts is called macculé-culé. It begins with the couple performing ablutions to clean and purify the body. Following ablution, assikalaibineng texts set out that a husband should greet his wife by saying assalamu 'alaikum (peace be upon you) before engaging in any sexual activity. If the wife is receptive, she will answer waalaikumussalam, a response that indicates she is ready to accept the invitation. This is followed by both verbal and physical actions initiated by the husband and includes stimulation of the wife's sexual organs. It is stipulated that a husband must remember this first stage and not directly insert his penis into the wife's vagina. This is because her sexual desire and emotion need to be stimulated first and she does not feel unprepared or forced into having sex. In addition to physical stimulation of a wife's sexual organs, a husband must pay attention to her psychological, emotional and spiritual needs before penetration can take place. A husband must therefore be sufficiently skilled and capable in creating the correct environment for sexual activity. That he is the initiator conforms to Bugis and Makasar models of sexuality concerning the different nature of men and women that is related to the cultural concept of siri', where it would be considered wholly inappropriate and unusual for a woman or wife to initiate sex. ${ }^{13}$ At the same time, assikalaibineng teaches that it is correct sexual procedure for the husband to pay attention to a wife's physical and emotional stimulation and that if she is not ready to have sex a husband should not proceed based on his desire alone.

Various assikalaibineng texts specifically teach a husband the art of foreplay in order to sexually arouse and stimulate his wife. This involves both kissing (manynyonyo') and touching (makkarawa) various sensitive parts of her body accompanied by specific Islamic prayers or mantras. Twelve sensual parts of the wife's body are mentioned in most texts that are considerd points of stimulation: forehead (buwung), ears (dacculing), between the eyebrows (lawa enning), eyes (mata), cheeks (pili), chin (sadang), lower neck (edda'), nape of the neck (cekkong), palms of the hand (pele' lima), breasts (panglolo), naval (posi'), and nose (inge'). Kissing and touching these parts is a way of stimulating sexual passion and these actions are considered fundamental in order for the next stage to take place. In particular, these acts of sexual stimulation are of importance for newlyweds and this is why assikalaibineng impresses upon a husband to provide correct foreplay so that a wife is physically and mentally prepared for sex on the first night of marriage. For the Bugis and Makasar elite, it is traditional for a male entering into marriage to first learn knowledge of assikalaibineng so 
he can correctly perform his sexual role in relation to his wife. Males who have attained knowledge of assikalaibineng sexual ways are referred to as orowané mapata (skilled man) as they are regarded as being able to provide a wife with quality sexual enjoyment and affection. On the other hand, a man who is married but does not have sufficient sexual knowledge is referred to as orowané bongngo (stupid man). An example of foreplay instructions that contain Bugis mantra (jappi-jappi) is set out below:

Then hold her stomach and say this three times, faraihun waraihanun wajannatu na'im. Blow on her hair, say nuurun alaa nuuing yahdi bihillah nuuur min syai. Kiss her left cheek three times and say [?]. Kiss her lower neck and say three times, bismillah laa iru lillahi jallallahu harajat may'atu rajulu. Kiss her breasts, then touch her naval. Hold her and say Inna fatahnaa laka fatham mubiina. Then say assalamu 'alaikum ya baabar rahmaan. The wife gives the following reply: Wa 'alaikumus salaam ya syyidal amiin. Continue by holding her thigh and read alloohumma jannibnasy syaihtoona wa jannibiy syaithoona ma razaktanaa birahmatika yaa arhamar-rahimiin.

Muinappana mattenniwwi babuwana mubacai iyawé-él Faraihun waraihanun wajannatu na'im/ wékka tellu/ Museppungngi/ u'na muinappasi bacai iyaél Nuurun alaa nuuing yahdi bihillah nuuur min syai/ Muinappasi towa'i pili'na wékka tellu ri abéo/ Mutowa'si edda'na muinappasi bacai iyaél Bismillah laa iru lillahi jallallahu harajat may'atu rajulu/ wékka tellu/ Mummoi susunna muinappa mattenniwwi posi'na/ Muinappasi mattenniwwi katauwwanna mubacai/ Inna fatahnaa laka fatham mubina /Muinappasi bérésellengiwi mubacai iyaél Assalamu 'alaikum ya baabur rahmaan/ Naribalitonasa ri makkunraiél Wa 'alaikumus salaam ya sayyidal amiin/ Muinappana mattenniwwi poppanna mubacai/ iyaél Alloohumma jannibnasy syaihtoona wa jannibis syaithoona ma razaktanaa birahmatika yaa arhamar-rahimiin (ANRIM 33/40, p. 64-67).

After the husband says assalamu 'alaikum ya Babur-rahman (peace be upon you, merciful door), the wife's response, waalaikumussalam sadikul mu'minin (peace be upon you, faithful friend), signals that she is ready for sexual intercourse. In addition to being an invitation for sex, the phrases 
have a deeper sexual meaning: sex should not simply be a union of two bodies but of pure hearts and souls that is a gift from God and has His blessing.

\section{Mabbarattemmu: The Second Stage}

The second phase, mabbarattemmu, is primarily concerned with the penetration of the husband's penis (kalamung) into the wife's vagina (sumpang) after she has indicated her desire and readiness. Before proceeding with penetration assikalaibineng texts instruct husbands to observe that his wife's vagina is open and its walls damp with fluid. The husband should be aware that the fluid functions as a lubricant and if not evident should restrain himself and delay penetration. This knowledge of the female sex organ is considered important for newlyweds as it can prevent a wife experiencing pain and also not make her feel as though she is simply serving her husband's desire. In relation to this, assikalaibineng provides a husband with guidance on vaginal stimulation.

In assikalaibineng the vagina is divided into four doors, or parts, each symbolically guarded by a wife of the Prophet Muhammad: Khadijah (top side), Salamah (bottom-side), Aisyah (right side) and Maemuna (left side). ${ }^{14}$ A detailed explanation of how to touch each vaginal door is presented below:

Position your penis, say ya 'adiyal hajati mufattikh iftakhna. Kiss her breasts, say ma katabal fakadung making. Then raise her hips and say allahumma jannibni mina syethani wa jannibis syaethani ma razaktana ya Allah Muhammad. The moment her vagina opens up like a flower in bloom, insert the head of your penis. If you intend to touch the right side of her vagina then bend your right leg and straighten her left leg. You will then touch the right side. Say subhanallah 33 times. If you intend to touch the left side of her vagina, straighten out her right leg and bend your left leg. You will then touch the left side. Say subhanallah 33 times. To touch the top side of her vagina raise her hips by four fingers. Then you will touch the top side. Read subhanallah 33 times. Then caress her thigh. Repeat all this from beginning then touch her clitoris, which is located near the urethra. This will give her great pleasure. Then hold and caress her breasts, kiss between them. Lie her in your lap and you will touch the bottom side of her vagina. Push only one third of your penis into her vagina. Then lie her down, stretch 
out her legs and touch the left side. Then lie down her right leg, pull her knees together and move her back and forth by the shoulders. Make sure you touch the right side as this will make her tremble with pleasure. To intensify enjoyment then lay the soles of her feet down. This will give her great pleasure. She will feel God's power. The end.

Mupangoloni kalamummu mubacasi iyaél Ya 'adiyal hajati mufattikh iftakhna/ Muinappasi baui arona mubacasi iyaé/ Ma katabal fakadung makang/ Nainappasi riakka timungenna mubacasi iyaél Allahumma jannibni minasyethani wa jannibis syaethani ma razaktana ya allah Muhammad/ Pada ppucunni katauwwammu padaé tosa pucunna bungaél Tapauttama'ni katauwwatta' angkanna sékkéna/ Narékko maéloko kkennai babangngé ri atau lokongngi ajé ataummu mupallempui Ajé abéona makkunraiél Majeppu mukennani ritu ri atau/ Bacasi yié wékka tellu ppulo tellu/ Subhanallah/ Narékko maéloko kkennai babangngé ri abéo pallempui ajé kananna makkunraié/ Mukennani ritu ri abéo/ Mubacasi iyaé wékka tellu ppulo tellu/ Subhanallah/ Narékko maélo' siko kkennai babangngé ri wawoé langgai eppa jari énré'na/ Majeppu mukennani ritu ri wawoél Mubacasi iyaé wékka tellu ppulo tellu/ Subhanallah/ Nainappa ssaulai [poppanna] makkunraié/ Mupammulasi paimeng nainappana pakennaiwi tengngana pallawangenna/ Kuwaé tosa timungeng jarungngé ri seddéna naolaé témél Namaserona mario makkunraél Naritéténna susunna makkunraiél Narimmona pattawa duwanna makkunraié/ Nari paléwuna ajéna ri wakkangetta'/ Mukennani ritu timungenna ri wawoél Mukira-kirani mupattellu ttawangngi/ Sikuwa mupattama' katauwwammu/ Duwa kuwa temmu puttama'/ Nainappa mupaléwu ajéna yiwali/ Nainappasi kkennai babangngé ri abéo/ Muinappasi paléwui ajé kananna/ Mupasitutui uttuna ri abéo/ naripakédo-kédo bongko'na makkunraiél Mukira-kirai ritu babang ri atau nacaggiri' makkunraiél Narékko maéloki' passukkui tapaléwui pale' kajéta'/ Maseroni ritu mariyo makkunraié naita toni asogirenna Alla taala/ Tammat (ANRIM 33/40, p. 80-83). 
According to assikalaibineng texts, touching the vaginal walls are techniques that provide both sexual variation and give a woman a high level of sexual enjoyment and satisfaction. In addition, assikalaibineng texts contain various other sexual actions and set out various intercourse positions. Some contain several erotic acts said to provide a woman with great pleasure and help her achieve an orgasm, such as in the following example:

Do not go straight to sleep at night. Arouse your wife's passion [and have sexual intercourse] if that is what you wish. When your penis has entered her then sit up on the soles of your feet. Maintain this position until you reach a climax. Bring together your mouths, your noses, eyes and forehead. Ensure the whole of your bodies meet as one. Move one hand to her clitoris and hold her head with the other. Stick out your tongues, [gently] bite her tongue, suck in her breath. Recite A-I-U. Say in your heart, "your body is absorbed by mine, your heart is absorbed my mine, your secrets are absorbed by mine, your desires are absorbed by mine. I take all your desires and needs. These I tie together in a white knot from the single great entity. Only if God parts with Muhammad will our desires and needs be separate. Let this be so." Repeat all actions as you have intercourse again. Correct your thoughts and feelings to God. Control your breathing so that it is in harmony with the thrusts of your penis.

Naiya rékko dépa natinro aja'sa tatalésang sangadinna iyapa soddiwi tainappana/ Nayi rékko muéloriwi makkunraimmu/ Narékko muttama'ni kalamung patokkonni mupatudangngi ri lébo'na palaka ajému/ iya dua mupaggangkani baté mpisoe kalamummu/ Pasitumpu' timummu na timunna/ Inge'mu na inge'na/ Matanna na matammu/ linrona na linromu/ Aja'na naengka lappa ri alému mupasiduppa manengngi ujungngé ri watakkalaému muparéwe'ni limammu siwali ri katauwwanna/ Siwali makkatenniwwi ulunna musoronni pacollonni lilamu mudadda'i muisoi nappase'na mupoadani sikkiri'é A-I-U / Nakkedana atimmu tubummu lenynyé ri rahasiyaku'/ Cinnamu lenynyé ri éloku' / Engka manenni uwala cinnamu élomu / Uparibekke mputéna ri Puang Séuwwaé / Massaraggi Allahu Taala Muhamma' nalé massarang cinna na élo'mu riya' / Kumpayakung / Muinappana palisui paimeng mupasibawai 
culé culé gau'mu ri laleng ngarému / Mupadécéngini paréngngerammu ri Alla Taala rampéna nyawamu / Taroi mapata assu' uttama'na nappase'mu sibawa rappena kalammu / (ANRIM 48/18 p. 84-87).

Some texts, such as ANRIM 48/8, state that the feeling of pleasure experienced at the height of sexual climax has no equal in this world. This pleasure and enjoyment is regarded as a great gift that God in His mercy gave to His creations.

\section{Taretté': The Third Stage}

The third stage follows the ejaculation of semen and is required in order for there to be an appropriate conclusion to sexual intercourse. After sexual climax, a husband still has responsibilities towards his wife and must not neglect her. These responsibilities include massaging and cleaning specific parts of her body, expressions of affection and actions that will help to maintain her youthfulness. These acts serve partly to ensure a husband continues to express love and affection for his wife following intercourse and not give the impression that he is no longer interested in her and has lost passion and desire after achieving his orgasm. Some of these instructions are given below.

When you ejaculate say Allahu akbar four times. Remove your body [from hers] while saying Alhamdulillah wa laa illallah nurung Muhammad habibillah. You then carry out actions that will please her feelings and make known your continuing affection. This should be done with care after you finish [intercourse]. When this is done drink three mouthfalls of water. When you have drunk the water take some ointment and massage your genitalia. This is so your body recovers and you will not become weak should you desire to repeat the act of sexual intercourse. This is said so that a man does not show disinterest in his wife.

Rékko mangujuni llao manimmu takabbéré'no wékka eppa/ urappe'ni alému mupassamangngi makkedaél Alhamdulillah wa laa illallah nurung Muhammad habibillah/ Narékko murappe'ni alému/ Gau'- gau'ni paimeng pammasé mariwawoiéngngi p. 76 padanna pammasél Narékko purani muwamaséi paluppungini madécénni/ Narékko purani 
mupaluppungi sorono muwala uwwaé muteggo'-i wékka tellu/ Narékko purani muteggo' alano minynya' passaula' musaularengngi katauwwammu apa' napoléiyyammi' [dodong] mupogaukengngi paimeng/ Apa' nasengngao mangingngi'/ Aja' mupappinrai gau'mu dénré puraé mupogau'/ Iyanaritu p. 77 riyaseng temmangingngi/ (ANRIM 33/40, p.75-77).

A number of texts further set out procedures a man should follow that serve to maintain the youth and beauty of his wife's body. This involves the use of spent procreative fluids, which are effectively returned to the body. A husband takes the mixed vaginal fluid and semen from his wife's vagina then places it in the right palm of his hand and stirs it with his middle finger. After reading a specific mantra (below), the husband wipes the fluid on specific parts of her upper body until the navel: the crown of the head (bubung), between the eybrows (lawa enning), the nose (inge'), the larynx (edda'), navel (posi), thigh (poppang), face (rupa), and then the remaining parts of her upper body to the navel (watakkalé gangkanna rupa). The Bugis mantra spoken before this follows below.

The fluid is mixed, the fluid is returned. Radience returns, radience returns like a full moon covered by the light of Muhammad, Fatimah's face is radient, [the radience] spreads in her body, spreads in her heart, in her soul. She will not die or age, always young. Let this be.

Waddu waddi mani manikang, Mani riparéwe', tajang mapparéwe'. tajang riapparéweki, natongko' ulettépu, nasalipuriwi caiyyana nurung Muhamma', énré'ko muaccayya ri rupanna I Patima muasse' ri tubunna muallebbang, ri atinna muradde' ri nyawana/ napakéo temmaté temmatowa malolo pulana/ Kumpayakung (ANRIM 48/18 p. 82-83).

In addition to the use of vaginal fluid and semen, several texts suggest a husband provide other care for his wife, such as wiping away her perspiration and gently massaging her limbs and joints. Before she falls asleep, marking the end of sexual intercourse, he should also sweet-talk her. These texts further express that if a wife wakes in the night the husband should stroke her body, hold her hair, kiss her cheek and then place her hand on his chest. Some also advise that a husband sleep with his wife in a single sarong after intercourse to show his affection remains unchanged after sex. The purpose of these actions is to teach a husband to show the same love 
and concern for his wife that he expressed when initiating sex. Such advice is consistently found in assikalaibineng texts.

\section{CONCLUSION}

Assikalaibineng is an indigenous Bugis and Makasar knowledge system of sexuality and sexual relations that absorbed Islamic values, specifically Sufi teachings that became the ideological basis of this knowledge. It has been narrated in both textual and oral form since the 17th century and continues to be known and practiced by a number of Bugis and Makasar, most of whom follow Sufi tariqa. A notable feature of these texts is that they place considerable emphasis on the sexual enjoyment of the female. This aspect can perhaps be seen as indigenous and equates with Reid's (1988: 148-50) picture of sexual relations in early modern Southeast Asia where there was an emphasis on the erotic pleasure of a women.

From the 17th century knowledge of assikalaibineng and the ownership and production of texts appears to have been largely exclusive, its practice limited to the social elite, such as upper and middle ranking nobility, and ulama or santri associated with tariqa. This exclusivity probably lessened in the 20th century with the rise of the Khalwatiah Samman but assikalaibineng knowledge was still largely restricted to tariqa followers.

The incorporation of Islamic values into Bugis and Makasar sexual culture appears to have brought a more ethical approach to sex, in particular for those of elite descent. Historical records reveal several cases of sexual exploitation by early Bugis rulers who abused their position. For example, the Boné ruler La Inca Matinroé ri Addénénna (1584-1595) is known to have raped unmarried girls and married woman before he was eventually murdered (Ali 1969: 22). Another example is the 18th century ruler of Bélawa, La Malloroseng, who intercepted women who passed by his palace and forced them to have sex. ${ }^{15}$ Improper sexual practice appears to have become less common among the elite with the development of assikalaibineng knowledge as it provided guidance and an ethical framework created from a combination of indigenous Bugis and Makasar and Sufi and sexual practices. 


\section{ACKNOWLEDGEMENT}

I would like to thank Stephen Druce and Ian Caldwell for their helpful criticisms and comments on an earlier draft of this paper.

\section{ENDNOTES}

* Muhlis Hadrawi lecturers in philology, literature and Bugis language at Hasanuddin University, Makassar, Indonesia. He obtained his MA research degree in philology in 2005 from Universitas Indonesia and his $\mathrm{PhD}$ in 2015 from Institut Alam dan Tamadun Melayu (ATMA), Universiti Kebangsaan Malaysia. His PhD research was a philological and historical study of the arrival and integration of Malays in South Sulawesi between the 16th and 17th centuries. He has written widely on various aspects of Bugis literature. His last book, Assikalaibineng kitab persetubuhan Bugis, (first published in 2008 and subsequently republished four times), had sold over 12,000 copies by 2010 and became a best-seller at Gramedia.

1 The author wrote this article in the Indonesian language specifically for this edition of International Journal of Asia Pacific Studies (IJAPS) with the agreement that the guest editor would translate and edit the text. Stephen C. Druce is the guest editor for this IJAPS' special issue on Orality, Writing and History: The Literature of the Bugis and Makasar of South Sulawesi.

2 Makasar (with one "s") refers to the ethnic group of that name and their language; Makassar refers to the capital of South Sulawesi, formerly Ujung Pandang.

3 Caldwell (1988) provides evidence to show that writing first developed among the Bugis at about 1400. Druce (2009: 61-63) suggests that the earliest writing was largely confined to the central eastern part of South Sulawesi, around the Cenrana and Walannae valleys, and was adopted later in other areas.

4 These texts were unreadable for the following reasons: excessive damage, smudged ink that made the text unintelligible, missing pages and failure of the microfilm process.

5 For a philological analysis and discussion of these texts, see Hadrawi (2008).

6 On Syekh Yusuf see Hamid (1994) and Tudjimah (1997).

7 Petta Tosalamaqé is commonly used in reference to Syekh Yusuf. He is also often referred to as Syekh Yusuf Petta Tosalama'é (see Hamid 1994: 128).

8 A surau is a small Muslim prayer house but are traditionally places of religious instruction and learning.

9 Bruinessen (1991: 251) cites 1973 figures from the Department of Religious Affairs that placed the number of Khalwatiyya Samman members at about 117,000 and the Khalwatiyya tariqa at 25,000. Pelras (1996: 290) cites the 1976 figures from the same department that estimated Khalwatiyya Samman membership to be 100,000 and 50,000 for the Khalwatiyya tariqa. A recent dissertation suggests membership of the Khalwatiyya Samman to be far greater that the above figures with membership running to hundreds of thousands, and 60,000 alone in the regency of Bone, the area the study focused on (Arfiandy 2015).

${ }^{10}$ For a more detailed philological analysis of these texts see Hadrawi (2008: 10-46). 
11 This interaction between the oral and written registers is a common feature of various South Sulawesi literature (Pelras 2016; Druce 2009: 37-90; Druce 2016).

12 This dialogue can be found in ANRIM 60/26.

13 On siri', see Hamid (1985) and Rahman (2016).

14 This is set out in ANRIM 33/40 p. 92-96. In some texts the wives are placed in a different order, for example, ANRIM 26/13 has the top side guarded by Aisyah, Maemunah the bottom side, Khadijah the right side and Salamah the left side.

15 The story of La Malloroseng is set out in ANRIM 79/5.

\section{REFERENCES}

Ali, M. 1969. Bone: Selayang pandang. Bone: Kantor Daerah Direktorat Jenderal Kebudayaan Kabupaten Bone.

Andaya, B. W. 2006. The flaming womb: Repositioning women in early modern Southeast Asia. Honolulu: University of Hawaii Press.

Arfiandy. 2015. Kepatuhan pengikut ajaran Khalwatiah Samman terhadap pemimpinnya pada Pemilu Legislatif 2014. Final year undergraduate diss., Hasanuddin University, Makassar, Indonesia.

Bruinessen, M. V. 1991. The tariqa Khalwatiyya in South Celebes. In Excursies in Celebes: Een bundel bijdragen bij het afscheid van J. Noorduyn als Directeur-Secretaris van het Koninklijk Instituut voor Taal-, Land- en Volkenkunde, eds. Poeze, H. A. and Schoorl, P., 251-269. Leiden: KITLV Press.

. 1999. Kitab kuning, pesantren dan tarekat. Bandung: Mizan.

Caldwell, I. A. 1988. South Sulawesi AD 1300-1600: Ten Bugis texts. PhD diss., Australian National University, Canberra.

Campo, J. E. 2004. Ahl al-Bayt. In Encyclopedia of Islam and the Muslim world, 6th ed., ed. Martin, R. C., 25-26. New York: Macmillan Reference USA.

Druce, S. C. 2009. The lands west of the lakes: A history of the Ajattappareng kingdoms of South Sulawesi, 1200 to 1600 CE. Leiden: KITLV Press. . 2016. Transmitting the past in South Sulawesi: The hikajat Sawitto and other Bugis and Makasar historical works. In Orality, writing and history: The literature of the Bugis and Makasar of South Sulawesi, ed. Druce, S. C. International Journal of Asia Pacific Studies 12 (Supp. 1): 73-117, http://dx.doi.org/10.21315/ijaps2016.12.s1.5.

Hadrawi, M. 1999. Mitos dan perilaku sexual: Tinjauan terhadap lontarak Bugis assikalaibeneng. Penelitian Dana Berbagai bagai Ilmu, Direktorat Pengembangan Penelitian dan Pengabdian pada Masyarakat Direktur Pendidikan Tinggi Departemen Pendidikan dan Kebudayaan. (unpublished report). . 2008. Assikalaibineng: Kitab persetubuhan Bugis. Makassar: Ininnawa. 
Hamid, A. 1985. Manusia Bugis-Makassar: Satu tinjauan historis terhadap tingkah laku dan pandangan hidup manusia Bugis Makassar. Jakarta: Inti Idayu. . 1994. Syekh Yusuf: Seorang ulama, Sufi dan pejuang. Jakarta: Yayasan Obor Indonesia.

Macknight, C. C. 1984. The concept of a "work" in Bugis manuscripts. Review of Indonesian and Malaysian Affairs 18: 103-114.

Paeni, M. et al. 2003. Katalog induk naskah nusantara Sulawesi Selatan. Jakarta: Arsip Nasional R.I (ANRI) Jakarta.

Pelras, Ch. 1996. The Bugis. Oxford: Blackwell. 2016. Orality and writing among the Bugis, transl. Macknight, C. C. In Orality, writing and history: The literature of the Bugis and Makasar of South Sulawesi, ed. Druce, S. C. International Journal of Asia Pacific Studies 12 (Supp. 1): 13-51, http://dx.doi.org/10.21315/ijaps2016.12.s1.3.

Rahman, N. 2016. The pau-paunna Indale Patara: Sufism and the Bugis adaption and transformation of the Hikayat Inderaputera. In Orality, writing and history: The literature of the Bugis and Makasar of South Sulawesi, ed. Druce, S. C. International Journal of Asia Pacific Studies 12 (Supp.1): 169-186, http://dx.doi.org/10.21315/ijaps2016.12.s1.8.

Reid, A. 1988. Southeast Asia in the age of commerce: 1450-1680, vol. I: The lands below the winds. New Haven and London: Yale University Press.

Tudjimah. 1997. Syekh Yusuf Makasar: Riwayat dan ajarannya. Jakarta: Universitas Indonesia.

Steigerwald, D. 2004. Ali (600-661). In Encyclopedia of Islam and the Muslim world, 6th ed., ed. Martin, R. C., 35-38. New York: Macmillan Reference USA. 